\title{
Quality assessment of mustard hilsa (Tenualosa ilisha) in various packing conditions during storage at low temperatures
}

\author{
F.H. SHIKHA, M.I. HOSSAIN AND S. MAHMUDA \\ Department of Fisheries Technology \\ Bangladesh Agricultural University, Mymensingh 2202, Bangladesh \\ *Email: ihossain.ft@bau.edu.bd
}

\begin{abstract}
Biochemical, microbiological and sensory quality parameters of mustard hilsa prepared from Hilsa shad (Tenualosa ilisha) were examined to observe the changes in quality during storage at refrigeration temperature $\left(5^{\circ}\right.$ to $\left.8^{\circ} \mathrm{C}\right)$ for 60 days and at frozen temperature $\left(-18^{\circ} \mathrm{C}\right.$ to $\left.-20^{\circ} \mathrm{C}\right)$ for 180 days. The moisture, protein, lipid, and ash content and $\mathrm{pH}$ value in mustard hilsa decreased compared to those obtained for fresh fish. On the other hand, TVB-N and peroxide values increased compared to the values found in fresh fish. At refrigeration temperature and frozen temperature moisture and ash contents increased but protein and lipid content decreased gradually throughout the storage period. $\mathrm{pH}$ value of the mustard hilsa reduced from 7.22 to 6.01 and 6.59 at refrigeration and frozen temperatures, respectively. The TVB-N value and peroxide value increased progressively throughout the storage period irrespective of storage temperatures. Rate of changes in different parameters of mustard hilsa was slower in vacuum sealed packs than non-sealed and sealed packs. The aerobic plate count of bacteria was increased in refrigeration temperature but the load of microbes was reduced at frozen temperatures. The result of sensory quality change showed that, irrespective of storage temperature and packing condition the scores of sensory quality parameters decreased with the progress of storage time though the decreasing rate was slower at frozen temperature. The study concluded that, at refrigeration temperature mustard hilsa might remain in acceptable condition up to 60 days and at frozen temperature for about 180 days in vacuum sealed pack.

Keywords: Shelf life, Mustard hilsa, Packing, Low temperature
\end{abstract}

\section{Introduction}

Hilsa (Tenualosa ilisha) has a wide range of distribution and occurs in marine, estuarine and riverine environments. Hilsa is very popular among the people of this country because of its special flavor, attractive appearance, and high socio-economic importance (Fischer and Bianchi, 1984, Sahoo et al. 2016). Hilsa contributes about $12 \%$ (5.17 million metric tons) of the total fish production of the country. With a few exceptions, an increasing trend of Hilsa production over the last three decades was found in Bangladesh.

Foods from the aquatic environment are a unique source of the essential nutrients (FAO 1999). Fish meat is basically composed of water (66-81\%), protein (16-21\%), carbohydrates $(<0.5 \%)$, lipids $(0.2-25 \%)$ and ash $(1.2-1.5 \%)$ and is considered to have important biological value (Santaella et al. 2007), due to the contribution of Essential Amino Acids (EAA) and micronutrients (McManus and Newton 2011), as well as, its high levels of fatty acids omega-3 and omega-6, higher than in most meat sold for human consumption (Gjedrem et al. 2012). Begum et al. (2016) determine the nutritional value of hilsa fish from the six selected regions in Bangladesh and they found- the moisture, protein, fat, carbohydrate and energy values $66.94 \pm 7.34$ to $72.04 \pm 5.77 \%, 18.95 \pm 3.97$ to $20.56 \pm 4.57 \%, 4.97 \pm 0.89$ to $8.21 \pm 1.87 \%$, and 
$3.08 \pm 0.68$ to $4.84 \pm 1.22 \%, 0.35 \pm 0.09$ to $0.72 \pm 0.05 \%$ and $128.38 \pm 11.43$ to $161.68 \pm 13.21$ $\mathrm{kcal} / 100 \mathrm{~g}$ respectively.

As an increasing trend in hilsa production is observed, along with casual cooking procedure different hilsa based "ready to eat" products could be developed and or some preservation techniques could be applied for the extension of shelf life of the prepared products. Thermal processing techniques are widely used to improve the quality and safety of food products and to extend the shelf life of the products. In peak season while hilsa is abundant in markets, popular products like "mustard ilish' could be prepared and make available in "ready to eat" form by applying proper preservation techniques for the out-going, busy consumers who intend to taste this testy-popular cuisine. Considering these points the present study was designed and carried out to observe the changes in quality parameters of mustard hilsa prepared in the laboratory and stored at low temperatures in three different packs. In this study, the changes in sensory quality attributes of mustard hilsa throughout the storage period also evaluated.

\section{Materials and Methods}

Sample Collection: A total of $9 \mathrm{~kg}$ hilsa shad was collected from Chandpur and transported to the Fish Processing and Quality Control Laboratory, BAU and kept at frozen temperature $\left(-18^{\circ} \mathrm{C}\right.$ to $\left.20^{\circ} \mathrm{C}\right)$.

Preparation of mustard hilsa: The ingredients used are presented in Table I. The fishes were thoroughly washed, cut into pieces and washed with tap water and kept in a dry tray. The fish slices were marinated with salt and turmeric. Mustard gravy was prepared by blending mustard seed with chili and salt. Fish slices were cooked with spices for about 3 min. Onion, garlic and ginger powder were fried till they turned to light brown color. Cumin powder, turmeric powder, chili powder was added. A small amount of salt and water were added to the oil and cooked for $1 \mathrm{~min}$. The mustard paste was mixed in $1 / 2$ cup of water and poured on the spices and cooked for $3 \mathrm{~min}$. The fish slices were added and cooked for 3 min on low flame. Cooking was continued for $8 \mathrm{~min}$ on low flame, cooled at low temperature.

Table I. Ingredients used for preparation of mustard hilsa

\begin{tabular}{lc}
\hline Ingredients & Amount of the ingredients \\
\hline Fish muscle & $500 \mathrm{~g}$ \\
Chili powder & $30 \mathrm{~g}$ \\
Turmeric powder & $5 \mathrm{~g}$ \\
Cumin powder & $10 \mathrm{~g}$ \\
Onion & $150 \mathrm{~g}$ \\
Garlic powder & $10 \mathrm{~g}$ \\
Ginger powder & $10 \mathrm{~g}$ \\
Mustard seed & $20 \mathrm{~g}$ \\
Mustard oil & $80 \mathrm{ml}$ \\
Salt & $30 \mathrm{~g}$ \\
\hline
\end{tabular}

Storage of mustard hilsa: For storage of the mustard hilsa samples three types of packs were used namely-non sealed pack, sealed pack and vaccum sealed pack. In each pack $30 \mathrm{~g}$ of mustard 
hilsa sample was taken and stored at refrigeration temperature $\left(5^{\circ} \mathrm{C}\right.$ to $\left.8^{\circ} \mathrm{C}\right)$ and frozen temperature $\left(-18^{\circ} \mathrm{C}\right.$ to $\left.-20^{\circ} \mathrm{C}\right)$ for 60 days and 180 days, respectively.

Quality analysis of mustard hilsa: For obtaining accurate result triplicate samples were taken for each sample. Proximate composition (percent moisture, protein, lipid and ash) of raw fish and mustard ilish were analyzed according to the methods described by AOAC (2007) with certain modifications. Total Volatile Base Nitrogen (TVB-N) was determined according to the methods given in AOAC (1984) with certain modification. The method for the determination of peroxide value was followed as described by Egan et al. (1981). $\mathrm{pH}$ was measured following the method described by AOAC (2007).

Microbial quality: Total Plate Count (TPC) of bacteria was done according to International Standard Organization (ISO, 1965) using the following formula:

\section{APC $($ CFU $/ \mathrm{g})=\frac{\text { No.of colonies on petridish } \times \text { Dilution factor } \times \text { Vol.of stock solution } \times 10}{\text { Wt. of mustard hilsa-sample }}$}

Sensory evaluation of mustard hilsa: Mustard ilish was tested by an expert panel, first. For the determination of sensory quality of mustard hilsa scoring test was used (Paulus et al., 1979). Prepared mustard ilish was served to 5 panelists to evaluate the sensory attributes (color, odor, taste, texture, general acceptability) of the samples by using 9-points descriptive scale. According to the scoring table, scores between 7-9 indicated 'high quality', scores between 4-6 indicated moderate quality and scores between 1- 3 indicated the limit of unacceptability.

Data analysis: Data from different biochemical measurements were subjected to statistical analysis. Data were processed using Microsoft Office Excel 2010. Data are represented within the view of table form and column diagram.

\section{Results}

\section{Changes in biochemical composition of mustard hilsa at refrigeration \& frozen temperature}

Moisture content: The moisture content (\%) of mustard hilsa showed an increasing trend with the progress of time irrespective of storage temperatures or packing conditions. On 0 day, moisture content $(\%)$ was found $63.3 \pm 0.01$ which increased to $65.8 \pm 0.80$ after 17 days of storage in non-sealed pack, $64.9 \pm 0.02$ in sealed pack after storage of 30 days and $65.9 \pm 0.10$ after storage of 60 days in vacuum sealed pack at refrigeration temperature while the values obtained $67.2 \pm 0.03$ for non-sealed pack after storage of 60 days, $65.5 \pm 0.26$ in sealed pack and $64.7 \pm 0.01$ in vacuum sealed pack samples after storage of 180 days at frozen temperature.

Ash content (\%): For ash content also a similar increasing trend was observed in mustard hilsa with the progress of time (Table II). Ash content (\%) of mustard hilsa was found $4.1 \pm 0.40$ on 0 day of storage, after 17 days of storage in non-sealed pack which increased to $8.3 \pm 0.12$, $9.4 \pm 0.11$ after storage of 30 days in sealed pack and $9.9 \pm 0.15$ after storage of 60 days in vacuum sealed pack at refrigeration temperature. On the other hand at frozen temperature the 


\section{QUALITY ASSESSMENT OF MUSTARD HILSA IN VARIOUS PACKING CONDITIONS}

values were found, $9.7 \pm 0.23$ for non-sealed pack sample after storage of 60 days, $9.8 \pm 0.03$ in sealed pack and $8.0 \pm 0.70$ in vacuum sealed pack samples after storage of 180 days.

Protein content (\%): Decrease in protein content (\%) of mustard hilsa samples was observed throughout the storage period (Table II). On 0 day of storage protein content (\%) value of mustard hilsa was $17.8 \pm 0.40$ which was decreased to $14.0 \pm 0.33$ after17 days of storage in non-sealed pack, $14.1 \pm 0.08$ in sealed pack after storage of 30 days and $14.1 \pm 0.01$ in vacuum sealed pack after storage of 60 days at refrigeration temperature while at frozen temperature the values were obtained $13.7 \pm 0.17$ for non-sealed pack sample after storage of 60 days, $13.1 \pm 0.33$ in sealed pack and $14.4 \pm 0.07$ in vacuum sealed pack samples after storage of 180 days.

Lipid content: A similar decreasing trend in lipid content (\%) was observed in mustard hilsa with the progress of time (Table II). On 0 day of storage, lipid content (\%) of mustard ilish was found $13.1 \pm 0.41$ which decreased to $11.0 \pm 0.38$ after 17 days of storage in non-sealed pack, in sealed pack $10.4 \pm 0.05$ after storage of 30 days and $10.7 \pm 0.02$ in vacuum sealed pack after storage of 60 days at refrigeration temperature. For frozen temperature the values were obtained- $9.8 \pm 0.22$ in non-sealed pack sample after storage of 60 days, $9.4 \pm 0.11$ in sealed pack and $10.0 \pm 0.02$ in vacuum sealed pack samples after storage of 180 days.

$\boldsymbol{p H}$ value: $\mathrm{pH}$ of mustard hilsa on 0 day was 7.22 which gradually decreased with the progress of storage time (Table II). At Refrigeration temperature, the value in non-sealed pack decreased to 6.06 after 17 days and to 6.32 in sealed pack after 30 days and in vacuum pack to 6.01 after 60 days of storage. On the other hand, at frozen temperature storage this decreasing rate in $\mathrm{pH}$ value was little slower; the $\mathrm{pH}$ value was 6.59 after 60 days of storage in non-sealed pack, 6.41 and 6.72 after storage of 180 days in sealed pack and in vacuum sealed pack respectively.

$\boldsymbol{T V B}-\boldsymbol{N}$ value: Immediately after preparation of mustard hilsa the TVB-N value was $2.84 \pm 0.01$ $(\mathrm{mg} / 100 \mathrm{~g})$ on 0 day which increased to $3.04 \pm 0.06$ in non-sealed pack after 17 days of storage, $3.10 \pm 0.06$ in sealed samples after 30 days of storage and $3.46 \pm 0.02$ in vacuum pack after 60 days of storage at refrigeration temperature (Table II). At frozen temperature, the values were, $3.01 \pm 0.91$ in non-sealed pack sample after storage of 60 days, $3.88 \pm 1.26$ in sealed pack sample and $3.45 \pm 0.05$ in vacuum sealed pack sample after 180 days of storage.

Peroxide (meq/kg of oil) value: On 0 day, the peroxide value of mustard hilsa was $5.44 \pm 0.40$, while the value increased gradually in the samples stored at refrigeration temperature (Table II). After 17 days of storage the peroxide value of mustard hilsa increased to $7.31 \pm 0.11$ in nonsealed pack, to $7.61 \pm 0.10$ in sealed pack after 30 days and to $7.71 \pm 0.08$ in vacuum sealed pack after 60 days of storage. On the other hand, in case of storage at frozen temperature the values were $7.45 \pm 0.05$ in non-sealed pack after storage of 60 days, $7.60 \pm 0.14$ in sealed pack and $7.89 \pm 0.05$ in vacuum sealed pack after 180 days of storage.

Aerobic plate count: The value of aerobic plate count was $3.5 \times 10^{4} \mathrm{CFU} / \mathrm{g}$ on 0 day in mustard hilsa, the value slightly increased to $3.1 \times 10^{5}$ in non-sealed pack, to $3.4 \times 10^{5}$ in sealed pack and to $5.2 \times 10^{5} \mathrm{CFU} / \mathrm{g}$ at refrigeration temperature (Table II). When the mustard hilsa stored at frozen temperature, at the end of 60 days of storage aerobic plate count decreased from $3.5 \times 10^{4}$ 
F.H. SHIKHA et al.

$\mathrm{CFU} / \mathrm{g}$ (on O day) to $7.3 \times 10^{2}$ in non-sealed pack, to $8.4 \times 10^{2}$ in sealed pack and to $6.6 \times 10^{2}$ in vacuum sealed pack after 180 days of storage at frozen temperature.

Table II. Changes in moisture, ash, protein and lipid contents and pH, TVB-N, peroxide and aerobic plate count values of mustard hilsa at refrigeration and frozen temperature

\begin{tabular}{|c|c|c|c|c|c|c|c|c|c|}
\hline $\begin{array}{l}\text { Packing } \\
\text { condition }\end{array}$ & $\begin{array}{l}\text { Storage } \\
\text { Days }\end{array}$ & $\begin{array}{c}\text { Moisture } \\
\text { content }(\%)\end{array}$ & $\begin{array}{c}\text { Ash } \\
\text { content } \\
(\%)\end{array}$ & $\begin{array}{c}\text { Protein } \\
\text { content }(\%)\end{array}$ & $\begin{array}{c}\text { Lipid } \\
\text { content } \\
(\%)\end{array}$ & $\mathrm{pH}$ & $\begin{array}{c}\text { TVB-N } \\
(\mathrm{mg} / 100 \mathrm{~g})\end{array}$ & $\begin{array}{l}\text { Peroxide value } \\
\text { (meq/kgof oil) }\end{array}$ & $\begin{array}{c}\mathrm{APC} \\
(\mathrm{CFU} / \mathrm{g})\end{array}$ \\
\hline \multicolumn{10}{|c|}{ Refrigeration temperature $\left(5^{\circ}\right.$ to $\left.8^{\circ} \mathrm{C}\right)$} \\
\hline \multirow[t]{4}{*}{ Nonsealed } & 0 & $63.3 \pm 0.01$ & $4.1 \pm 0.40$ & $17.8 \pm 0.40$ & $13.1 \pm 0.40$ & 7.22 & $2.84 \pm 0.01$ & $5.44 \pm 0.40$ & $3.5 \times 10^{4}$ \\
\hline & 3 & $64.3 \pm 0.02$ & $5.8 \pm 0.02$ & $15.8 \pm 0.01$ & $12.3 \pm 0.32$ & 6.97 & $2.96 \pm 0.02$ & $5.98 \pm 0.11$ & $3.7 \times 10^{4}$ \\
\hline & 10 & $64.6 \pm 0.78$ & $7.4 \pm 0.07$ & $14.5 \pm 0.20$ & $11.1 \pm 0.20$ & 6.61 & $2.98 \pm 0.02$ & $6.54 \pm 0.20$ & $2.5 \times 10^{5}$ \\
\hline & 17 & $65.8 \pm 0.80$ & $8.3 \pm 0.12$ & $14.0 \pm 0.33$ & $11.0 \pm 0.38$ & 6.06 & $3.04 \pm 0.06$ & $7.31 \pm 0.11$ & $3.1 \times 10^{5}$ \\
\hline \multirow[t]{4}{*}{ Sealed } & 0 & $63.3 \pm 0.01$ & $4.1 \pm 0.40$ & $17.8 \pm 0.40$ & $13.1 \pm 0.40$ & 7.22 & $2.84 \pm 0.01$ & $5.44 \pm 0.40$ & $3.5 \times 10^{4}$ \\
\hline & 5 & $63.8 \pm 0.04$ & $5.7 \pm 0.08$ & $15.6 \pm 0.11$ & $12.3 \pm 0.21$ & 6.96 & $2.96 \pm 0.02$ & $6.51 \pm 0.10$ & $3.8 \times 10^{4}$ \\
\hline & 20 & $64.3 \pm 0.18$ & $7.6 \pm 0.14$ & $15.0 \pm 0.10$ & $11.6 \pm 0.12$ & 6.61 & $2.98 \pm 0.02$ & $7.34 \pm 0.20$ & $4.2 \times 10^{4}$ \\
\hline & 30 & $64.9 \pm 0.02$ & $9.4 \pm 0.11$ & $14.1 \pm 0.08$ & $10.4 \pm 0.05$ & 6.32 & $3.10 \pm 0.06$ & $7.61 \pm 0.10$ & $3.4 \times 10^{5}$ \\
\hline \multirow{5}{*}{$\begin{array}{l}\text { Vacuum } \\
\text { sealed }\end{array}$} & 0 & $63.3 \pm 0.01$ & $4.1 \pm 0.40$ & $17.8 \pm 0.40$ & $13.1 \pm 0.40$ & 7.22 & $2.84 \pm 0.01$ & $5.44 \pm 0.40$ & $3.5 \times 10^{4}$ \\
\hline & 7 & $63.5 \pm 0.06$ & $5.6 \pm 0.04$ & $16.1 \pm 0.10$ & $12.6 \pm 0.02$ & 6.82 & $2.98 \pm 0.02$ & $6.22 \pm 0.10$ & $3.8 \times 10^{4}$ \\
\hline & 20 & $64.6 \pm 0.37$ & $6.0 \pm 0.19$ & $15.2 \pm 0.10$ & $12.0 \pm 0.18$ & 6.48 & $3.04 \pm 0.47$ & $6.42 \pm 0.10$ & $4.9 \times 10^{4}$ \\
\hline & 30 & $65.3 \pm 0.20$ & $7.6 \pm 0.22$ & $14.6 \pm 0.40$ & $11.3 \pm 0.04$ & 6.13 & $3.18 \pm 0.26$ & $7.51 \pm 0.40$ & $4.1 \times 10^{5}$ \\
\hline & 60 & $65.9 \pm 0.10$ & $9.9 \pm 0.15$ & $14.1 \pm 0.01$ & $10.7 \pm 0.02$ & 6.01 & $3.46 \pm 0.02$ & $7.71 \pm 0.08$ & $5.2 \times 10^{5}$ \\
\hline \multicolumn{10}{|c|}{ Frozen temperature $\left(-18^{\circ}\right.$ to $\left.-20^{\circ} \mathrm{C}\right)$} \\
\hline \multirow[t]{6}{*}{ Non sealed } & 0 & $63.3 \pm 0.01$ & $4.1 \pm 0.40$ & $17.8 \pm 0.40$ & $13.1 \pm 0.40$ & 7.22 & $2.84 \pm 0.01$ & $5.44 \pm 0.40$ & $3.5 \times 10^{4}$ \\
\hline & 10 & $63.7 \pm 0.20$ & $5.7 \pm 0.13$ & $16.3 \pm 0.19$ & $11.9 \pm 0.19$ & 6.95 & $2.85 \pm 0.02$ & $5.98 \pm 0.10$ & $3.3 \times 10^{4}$ \\
\hline & 15 & $64.0 \pm 0.13$ & $7.6 \pm 0.40$ & $15.5 \pm 0.03$ & $11.1 \pm 0.03$ & 6.90 & $2.85 \pm 0.05$ & $6.30 \pm 0.13$ & $3.9 \times 10^{3}$ \\
\hline & 25 & $64.3 \pm 0.22$ & $8.2 \pm 0.22$ & $14.8 \pm 0.23$ & $10.8 \pm 0.13$ & 6.87 & $2.87 \pm 0.04$ & $6.42 \pm 0.09$ & $3.2 \times 10^{3}$ \\
\hline & 40 & $64.8 \pm 0.09$ & $8.8 \pm 0.30$ & $14.1 \pm 0.02$ & $10.1 \pm 0.02$ & 6.85 & $2.96 \pm 0.02$ & $7.23 \pm 0.05$ & $2.3 \times 10^{3}$ \\
\hline & 60 & $67.2 \pm 0.03$ & $9.7 \pm 0.23$ & $13.7 \pm 0.17$ & $9.8 \pm 0.22$ & 6.59 & $3.01 \pm 0.91$ & $7.45 \pm 0.05$ & $7.3 \times 10^{2}$ \\
\hline \multirow[t]{6}{*}{ Sealed } & 0 & $63.3 \pm 0.01$ & $4.1 \pm 0.40$ & $17.8 \pm 0.40$ & $13.1 \pm 0.40$ & 7.22 & $2.84 \pm 0.01$ & $5.44 \pm 0.40$ & $3.5 \times 10^{4}$ \\
\hline & 15 & $63.8 \pm 0.31$ & $5.6 \pm 0.10$ & $16.3 \pm 0.01$ & $12.1 \pm 0.05$ & 7.13 & $2.85 \pm 0.24$ & $5.77 \pm 0.01$ & $3.1 \times 10^{4}$ \\
\hline & 45 & $64.8 \pm 0.03$ & $7.5 \pm 0.20$ & $15.6 \pm 0.10$ & $11.5 \pm 0.20$ & 7.02 & $2.96 \pm 0.02$ & $6.42 \pm 0.10$ & $4.8 \times 10^{3}$ \\
\hline & 75 & $64.9 \pm 0.08$ & $8.6 \pm 0.09$ & $14.4 \pm 0.05$ & $10.7 \pm 0.03$ & 6.85 & $3.15 \pm 0.07$ & $6.63 \pm 0.05$ & $4.2 \times 10^{3}$ \\
\hline & 120 & $65.0 \pm 0.12$ & $9.5 \pm 0.62$ & $13.4 \pm 0.26$ & $9.7 \pm 0.06$ & 6.64 & $3.39 \pm 0.21$ & $6.77 \pm 0.26$ & $9.3 \times 10^{2}$ \\
\hline & 180 & $65.5 \pm 0.26$ & $9.8 \pm 0.03$ & $13.1 \pm 0.33$ & $9.4 \pm 0.11$ & 6.41 & $3.88 \pm 1.26$ & $7.60 \pm 0.14$ & $8.4 \times 10^{2}$ \\
\hline \multirow{5}{*}{$\begin{array}{l}\text { Vacuum } \\
\text { sealed }\end{array}$} & 0 & $63.3 \pm 0.01$ & $4.1 \pm 0.40$ & $17.8 \pm 0.40$ & $13.1 \pm 0.40$ & 7.22 & $2.84 \pm 0.01$ & $5.44 \pm 0.40$ & $3.5 \times 10^{4}$ \\
\hline & 30 & $63.5 \pm 0.02$ & $5.2 \pm 0.03$ & $16.7 \pm 0.20$ & $12.8 \pm 0.05$ & 7.13 & $2.85 \pm 0.01$ & $5.72 \pm 0.20$ & $3.3 \times 10^{4}$ \\
\hline & 60 & $63.9 \pm 0.32$ & $6.8 \pm 0.30$ & $16.0 \pm 0.06$ & $11.9 \pm 0.01$ & 7.02 & $3.03 \pm 0.91$ & $6.36 \pm 0.06$ & $6.4 \times 10^{3}$ \\
\hline & 120 & $64.3 \pm 0.05$ & $7.5 \pm 0.50$ & $15.6 \pm 0.35$ & $10.6 \pm 0.35$ & 6.95 & $3.87 \pm 0.35$ & $6.82 \pm 0.35$ & $7.1 \times 10^{2}$ \\
\hline & 180 & $64.7 \pm 0.01$ & $8.0 \pm 0.70$ & $14.4 \pm 0.07$ & $10.0 \pm 0.02$ & 6.72 & $3.45 \pm 0.05$ & $7.89 \pm 0.05$ & $6.6 \times 10^{2}$ \\
\hline
\end{tabular}

* mean value \pm standard deviation of 3 individual measurements

Changes of sensory quality of mustard hilsa: At refrigeration temperature, the color, taste and general appearance of the product did not change markedly until 30 days irrespective of packing condition (Fig. 1). From day 45 almost all the parameters were found to be deteriorated. On the other hand when the mustard hilsa samples were stored at frozen temperature, the rate of change in sensory quality parameters was observed slower and until 60 days of storage the sensory 
quality parameters remained acceptable. With the extension of storage duration the sensory quality parameters deteriorated but none of them was considered as unacceptable.

\section{Discussion}

Proximate Composition: Kamal et al. (1996) observed no changes in proximate composition of hilsa fish (T. ilisha) during frozen storage at $-20^{\circ} \mathrm{C}$ for a period of 75 days. It is generally known that freezing leads to evaporation of moisture from the surface of the fish resulting changes in texture, particularly shrinkage and weight loss. Kamal et al. (1996) found little variation in moisture content might be due to protective effect of polythene which effectively prevented the removal of moisture from the fish body. They also observed a slightly lower value of protein after 60 days of storage which was might be associated with the potential denaturation effect of protein. In addition a potential denaturing effect of low $\mathrm{pH}$ on myofibrillar protein during frozen storage has also been taken into account by other researchers (Scott et al. 1988). The results obtained in the present study for proximate composition analysis are more or less in agreement with the above mentioned finding and explanations.

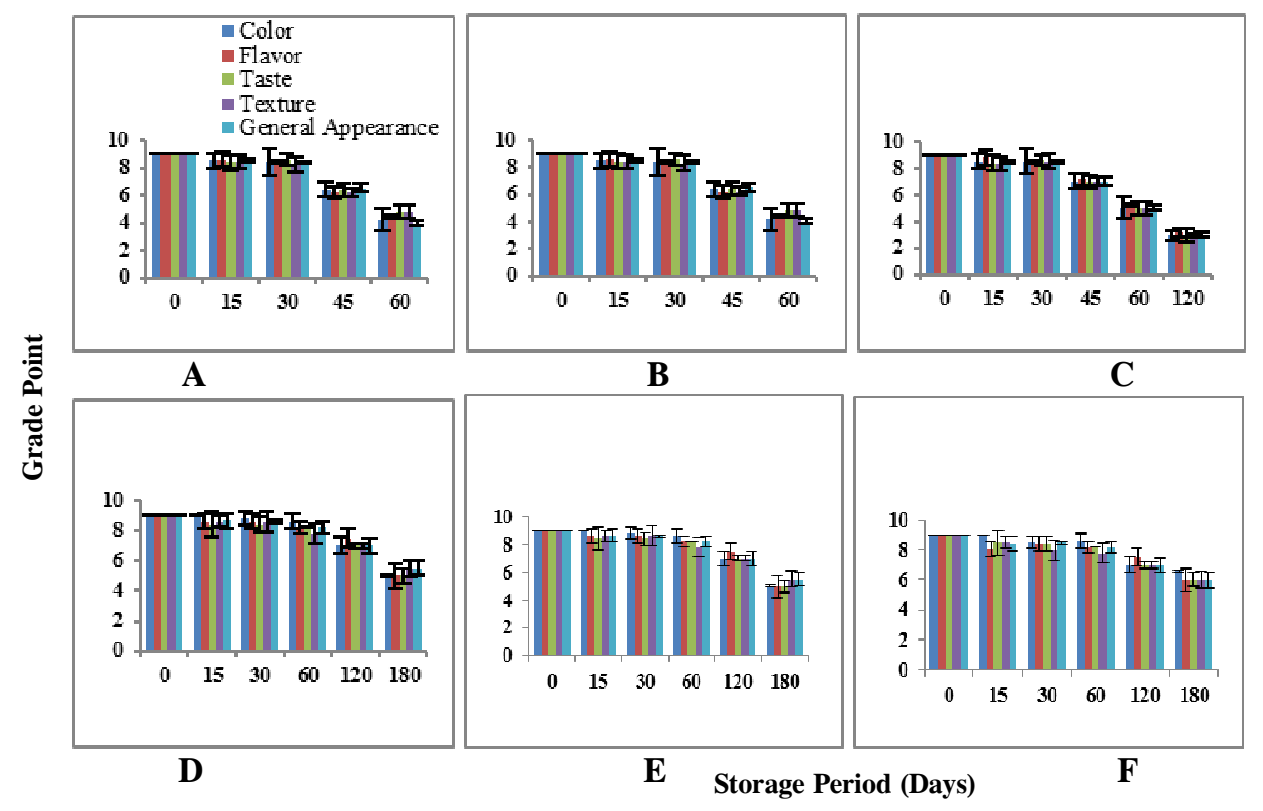

Fig. 1. Changes in sensory quality attributes of mustard hilsa in non-sealed, sealed and vacuum sealed packs at refrigeration $\left(5^{\circ} \mathrm{C}\right.$ to $\left.8^{\circ} \mathrm{C}\right)$ and frozen $\left(-18^{\circ} \mathrm{C}\right.$ to $\left.-20^{\circ} \mathrm{C}\right)$ temperatures (Where, A-non sealed;

$\mathrm{B}$-sealed; C-vacuum sealed pack samples at refrigeration temperature and D-non sealed; E-sealed; F-vacuum sealed pack samples at frozen temperature).

$\boldsymbol{p H}$ value: In the present study $\mathrm{pH}$ of mustard hilsa decreased at both storage temperatures irrespective of packing condition. Decrease in $\mathrm{pH}$ of fish ball in curry could be due to the growth of heat tolerant bacteria during storage that had survived at heat processing and then multiplied at chilling temperature (Kolekar and Pagarkar 2013). 
TVB-N value: Kamal et al. (1996) observed an increase in TVB-N value of hilsa during 75 days of frozen storage from initial value of $5.6 \mathrm{mg} / 100 \mathrm{~g}$ to $27.2 \mathrm{mg} .100 \mathrm{~g}$. Mugel et al. (2015) reported an increase in the TVB-N values, $4.67 \mathrm{mg} \%$ on $1^{\text {st }}$ day and $11.3 \mathrm{mg} \%$ on $20^{\text {th }}$ day of storage for fish ball prepared from tilapia mince (with $2 \%$ potassium sorbate) and stored at chilled condition. These findings are in agreement with the results obtained for TVB-N values of mustard hilsa in the present study. The TVB-N value of the samples though increased but all the values were below to the maximum value of $35 \mathrm{mg} \mathrm{N} / 100 \mathrm{~g}$ flesh specified by the EC guidelines (Commission Decision 95/149/EC 1995) for different species of raw fish.

Peroxide value: An increase in peroxide value from an initial value of the oil $5.53 \mathrm{meq} / \mathrm{kg}$ to $16.2 \mathrm{meq} / \mathrm{kg}$ for hilsa during 75 days of frozen storage was observed as the oxidation process proceeded (Kamal et al.1996). Praneetha et al. (2015) found that- peroxide value of fish finger of rohu increased from 10.73 to $17.8 \mathrm{meqO} 2 / \mathrm{kg}$ of fat till the end of $5^{\text {th }}$ day of storage which are more or less similar to the findings of present the study.

Aerobic plate count: Rahman et al. (2019) found the APC of bacteria Thai pangasius pickle $4.4 \times 10^{4}$ and $3.3 \times 10^{4}$ for refrigeration and frozen temperature storage, respectively which increased to $6.5 \times 10^{6}$ at refrigeration temperature but decreased to $6.8 \times 10^{2}$ at frozen temperature on the $12^{\text {th }}$ month of storage. In case of freezing, bacterial load decreased gradually might be due to frozen temperature that completely inhibits the bacterial growth in fish condiment. By halting the metabolic activity of such microorganisms present in and on the fish condiment, freezing stops this type of spoilage. Shikha et al. (2019) found the initial aerobic plate count of bacteria $2.1 \times 10^{4}$ of mola fish pickle, after 150 days of storage the count reached to $6.6 \times 10^{5}$ at refrigeration temperature but at frozen temperature storage the aerobic plate count decreased to $3.6 \times 10^{2}$ after 300 days of storage. All these findings are quite similar to the obtained results in the present study.

Changes in sensory quality parameters of mustard hilsa: In an organoleptic evaluation of frozen stored hilsa Kamal et al. (1996) found that- until 30 days of storage hilsa remained in good condition, after that fish gradually became pale, soft with slimy surface but no objectionable odor. Vanitha et al. (2013) found that fish cutlets and fish burgers prepared from catla minced meat were highly acceptable even at the end of 90 days of storage at frozen condition and the shelf life of fish cutlets and fish burgers was found to be 180 and 176 days, respectively.

Conclusions: The percent moisture and ash content increased but the protein and lipid content of mustard hilsa decreased with the progress of time irrespective of storage temperature and packing condition. TVB-N and peroxide values of mustard hilsa also increased from their initial values though the level of increment in values was low at frozen temperature. The result of sensory quality change showed that, with the progress of storage period the scores of sensory parameters decreased indicating deterioration of quality but the rate was slower at frozen temperature. Therefore, on the basis of obtained results the study could be concluded asmustard hilsa may remain in acceptable condition up to 60 days at refrigeration temperature and 180 days at frozen temperature $\left(-18^{\circ} \mathrm{C}\right.$ to $\left.-20^{\circ} \mathrm{C}\right)$ in vacuum sealed pack. 


\section{QUALITY ASSESSMENT OF MUSTARD HILSA IN VARIOUS PACKING CONDITIONS}

\section{Literature Cited}

AOAC, 1984. Official Methods of Analysis. Association of Official Analytical Chemists International, $15^{\text {th }}$ ed Washington DC.

AOAC, 2007. Official Methods of Analysis. Association of Official Analytical Chemists International, 18th edition, Washington DC.

Begum, M.S., Bhowmik, F.M. Juliana and M.S. Hossain, 2016. Effect of treatments (Lemon, Mustard and Garlic) on the quality of smoked Hilsa (Tenualosa ilisha) during storage seriods. J. Food Proce. Technol., 7:10.

Egan, H., R.S. Krik and R. Sawyer, 1981. Pearson's chemical analysis of foods. Churchil Livingstone, Edinburgh, UK. p.437, 458-459, 499, 533-536.

FAO, 1999. World production of fish, crustaceans and mollusks by major fishing areas. Fisheries Information Data and Statistics Unit (FIDI), Fisheries Department, FAO, Rome, Italy p: 33.

Fischer, W. and G. Bianchi (eds.), 1984. FAO Species Identification Sheets for Fishery Purposes. Western Indian Ocean (Fishing Area 51). Prepared and Printed with the Support of the Danish International Development Agency (DANIDA). FAO, Rome, Vol. 1-6.

Gjedrem, T., N. Robinson and M. Rye, 2012. The importance of selective breeding in aquaculture to meet future demands for animal protein: A review. Aquaculture. 350: 117129.

Kamal, M., M.N. Islam, M.A. Mansur, M.A. Hossain and M.A.I. Bhuiyan, 1996. Biochemical and sensory evaluation of hilsa fish (Hilsa ilisha) during frozen storage. Indian. J. Mar. Sci., 25: 320-323.

Kolekar, A.D. and A.U. Pagarkar, 2013. Quality evaluation of ready-to-eat fish ball in curry. SAARC J. Agric., 11(1): 35-43.

McManus, A. and W. Newton, 2011. Seafood, nutrition and human health. A synopsis of the nutritional benefits of consuming seafood. In: Centre of Excellence Science, Seafood and Health p: 5.

Mugale, R., S.B. Patange, V.R. Joshi, G.N. Kulkarni and M.M. Shirdhankar, 2018. Heat penetration characteristics and shelf Life of ready to serve eel curry in retort Pouch. Int. J. Curr. Microb. Appl. Sci., 7(2): 89-100.

Paulus, K., R. Zacharias, L. Robinson and H. Geidel, 1979. Critical Betrachtungenzur "evaluator test with the scale" as a method essentially the Sensorichen analysis. Groc Tote Wiss Techn., 12: 52-61 (in German).

Praneetha, S.S., K. Dhanapal, G.V.S. Reddy and A. Balasubramanian, 2015. Development of fish finger from rohu (Labeo rohita) and its quality evaluation during freezing storage condition. Int. J. Sci. Environ. Technol., 4(6): 1457 - 1468.

Rahman, M., M.I. Hossain and F.H. Shikha, 2019. Changes in the nutritional composition of fish pickle prepared from Thai pangus (Pangasianodon hypophthalmus) during longer storage at low temperature. J. Food Sci. Nutr. Res., 2: 299-308.

Sahoo, A.K., M.A. Wahab, M. Phillips, A.A. Rahman, V. Padiyar, R. Puvanendran, B. Bangera, D.K. Belton, D.K. De, B.K. Meena, A.P. Behera, A.P. Sharma, U. Bhaumik, B. P. Mohanty, S.R. Choudhury and C.V. Mohan. 2016. Breeding and culture status of Hilsa (Tenualosa ilisha, Ham. 1822) in South Asia: a review. Reviews in Aquaculture, 10: 96110. 
Santaella, M., G.M. Martínez, J. Periago, 2007. Comparison of wild and cultivated Ludubina (Dicentrarchus labrax): chemical composition and variation of fatty acid content after cooking. Anal. Vet. Murc., 23: 105-119.

Scott, D.N., R.W. Porter, G. Kudo, R. Miller and B. Koury, 1988. Effect of freezing and frozen storage of Alaska Pollock on the chemical and gel-forming properties of surimi $J$. Food Sci., 53: 353-358

Vanitha, M., K. Dhanapal and G.S.V. Reddy, 2015. Quality changes in fish burger from Catla (Catla catla) during refrigerated storage. J. Food Sci. Technol., 5: 1766-1771.

(Manuscript received 19 September 2020) 